Brit. J. prev. soc. Med. (1956), 10, 1-14

\title{
HEIGHTS AND WEIGHTS OF SCOTTISH SCHOOLCHILDREN
}

\author{
BY \\ J. A. GRANT KEDDIE \\ Formerly Medical Officer (School Health), Department of Health for Scotland
}

The series of investigations which form the subject of this account deal on a broad basis with questions relating to the height and weight of children attending Scottish education authority schools.

\section{OBJECT AND SCOPE OF INQUIRY}

Attention is given solely to cross-sectional or distance studies, that is to say, to the measurements at various ages of large numbers of children of different generations or of different geographicalindustrial groups.* Concern is with children aged $5,9,13$, and, in certain instances, 16 years, these being the ages at which children attending education authority schools undergo systematic medical examination in Scotland.

The material for presentation and analysis is divisible into four groups:

(1) Average heights and weights of children in Edinburgh and Glasgow during the past 40 years, 1913-14 to 1953-54.

(2) Average heights and weights of children in three of Scotland's main cities (Edinburgh, Glasgow, and Dundee) and one of its most populous counties (Ayrshire), the four areas together forming a representative cross-section of the school population in the central industrial belt, for the six school sessions, $1948-49$ to $1953-54$.

(3) Average heights and weights of Scottish children on a regional basis, for the sessions 1951-52 and 1952-53.

(4) Average heights and weights of children of four highly industrial large burghs (Dumbarton, Falkirk, Kilmarnock, and Kirkcaldy) and four less

* Nearing completion is a further series of investigations which relate both to the cross-sectional studies, in respect of school children of different socio-economic groups, and to longitudinal or velocity studies. industrial large burghs (Perth, Stirling, Ayr, and Dunfermline), 1952-53.

\section{Details of InVestigations}

(1) Edinburgh and Glasgow: Mean Heights and Weights of Children attending Education Authority SChOOLS EXAmined at Systematic MEdicAl InSPECTIONS AT 5, 9, AND 13 yeARS, AT INTERVALS FROM 1913-14 TO 1953-54.

In Scotland, relatively few education authorities can provide, from the early years of the school health service up to the present time, anything approaching a complete record of the average heights and weights of children aged 5, 9, and 13 years. This is due in part to the variation that existed from area to area, before session 1938-39, in the age groups selected for systematic medical examination. Glasgow is fortunately placed in this respect, but this circumstance has not been without disadvantage, for, as a consequence of the frequent quotation of the relatively low average heights and weights for Glasgow schoolchildren of 30 or 40 years ago and the relatively high increases in the average measurements of the children of that city in the past 20 years, there has been a tendency to accept these increases as typical of those of Scottish schoolchildren as a whole.

It is certain that there has been a general increase in the average heights and weights of schoolchildren of the various age groups (dealt with at systematic medical examinations) throughout Scotland during the past two decades, but, in the absence of reasonably complete records of past heights and weights for a representative cross-section of the school population, the precise extent of the increases for Scottish schoolchildren as a whole during the period in question must remain a matter for conjecture. 
Even the somewhat less marked increases in the average measurements of children attending Edinburgh education authority schools cannot be accepted as representative of those for Scottish schoolchildren as a whole, but the particulars for Edinburgh and Glasgow together may justifiably be regarded as illustrating such increases in most populous industrial centres during recent decades.

Appendix Table A, which deals with the average heights and weights of children aged 5, 9, and 13 years attending education authority schools in Edinburgh and Glasgow, shows the extent to which the average measurements have increased during the course of the past 40 years in these two cities. The choice of school sessions at irregular intervals is occasioned by the non-existence of height and weight records for Edinburgh schoolchildren during the recent war and by the fact that in that city, for a period of some years, not only was the systematic medical examination of the 9-year-olds discontinued but the examination of the older children was postponed from age 12 to age 13 .

In Appendix Table $A$ the actual average measurements of the schoolchildren of both Edinburgh and Glasgow for sessions 1953-54 and 1949-50 (and for 1937-38 as well in the case of Glasgow) have been adjusted to the uniform ages of $5 \frac{4}{1 \frac{1}{2}}, 9 \frac{5}{12}$, and $13 \frac{5}{12}$ years, use being made of the factors (that is, the average rates of increase in height and weight per month of age) employed in Glasgow in recent years in the adjustment of the average measurements of the local children to these particular uniform ages. As to the earlier sessions, the average ages when the children were measured approximated closely to the uniform ages mentioned above.

Two points are worthy of note:

(a) The average heights and weights for 1953-54 for boys and girls of all these age groups in both Edinburgh and Glasgow are greater than the corresponding averages for 1913-14, and all the differences are statistically significant.* The actual mean differences are set out in Table I.

At the end of the first world war and in the school sessions immediately thereafter, it was found that most of the average heights and.weights fell short of those recorded in session 1913-14. By 1931-32 a few of the average heights and weights given in Appendix Table A had shown signicant increases over those for 1913-14, but it is during the past 20 years that the increase in average measurements has steadily risen to a level approaching that for 1953-54.

Special comment is desirable concerning the average

\footnotetext{
* In this article, instances where the amount by which an observed difference exceeds its standard error is not stated with precision, the use of the word "significant" implies that the difference between two proportions or two averages is at least twice its standard error.
}

TABLE I

CITIES OF EDINBURGH AND GLASGOW EDUCATION AUTHORITY SCHOOLCHILDREN

INCREASE IN MEAN HEIGHTS AND WEIGHTS BETWEEN 1913-14 AND 1953-54

\begin{tabular}{|c|c|c|c|c|c|c|c|}
\hline \multicolumn{2}{|c|}{ Age (yrs) } & \multicolumn{2}{|c|}{5} & \multicolumn{2}{|c|}{9} & \multicolumn{2}{|c|}{13} \\
\hline City & & $\begin{array}{l}\text { Edin- } \\
\text { burgh }\end{array}$ & $\begin{array}{l}\text { Glas- } \\
\text { gow }\end{array}$ & $\begin{array}{l}\text { Edin- } \\
\text { burgh }\end{array}$ & $\begin{array}{l}\text { Glas- } \\
\text { gow }\end{array}$ & $\begin{array}{l}\text { Edin- } \\
\text { burgh }\end{array}$ & $\begin{array}{l}\text { Glas- } \\
\text { gow }\end{array}$ \\
\hline \multirow{2}{*}{ Boys } & $\begin{array}{l}\text { Increase in } \\
\text { Mean Height } \\
\text { (in.) }\end{array}$ & $1 \cdot 29$ & $1 \cdot 93$ & 2.92 & $4 \cdot 00$ & $3 \cdot 57$ & $3 \cdot 91$ \\
\hline & $\begin{array}{l}\text { Increase in } \\
\text { Mean Weight } \\
\text { (lb.) }\end{array}$ & $2 \cdot 07$ & $4 \cdot 35$ & $7 \cdot 45$ & $8 \cdot 36$ & $14 \cdot 37$ & $14 \cdot 53$ \\
\hline \multirow{2}{*}{ Girls } & $\begin{array}{l}\text { Increase in } \\
\text { Mean Height } \\
\text { (in.) }\end{array}$ & $1 \cdot 04$ & $1 \cdot 64$ & $2 \cdot 30$ & $2 \cdot 53$ & 0.85 & $3 \cdot 18$ \\
\hline & $\begin{array}{l}\text { Increase in } \\
\text { Mean Weight } \\
\text { (lb.) }\end{array}$ & $1 \cdot 31$ & $3 \cdot 69$ & $7 \cdot 19$ & $6 \cdot 98$ & $12 \cdot 68$ & $16 \cdot 41$ \\
\hline
\end{tabular}

height of 13-year-old Edinburgh schoolgirls. This was 59 in. in 1913-14, but the average height from 1909-10 to 1926-27 was regularly between 56 and 57 in. (1912-13, with 58.4 in., and 1913-14, with 59 in., being exceptional), and it was not until 1927-28 that an average height of $58.5 \mathrm{in}$. was reached. With this point in mind, therefore, it may be stated in general terms that between 1913-14 and 1953-54 the following increases took place in the average measurements of Edinburgh and Glasgow schoolchildren (Table II).

TABLE II

CITIES OF EDINBURGH AND GLASGOW EDUCATION AUTHORITY SCHOOLCHILDREN

APPROXIMATE GAINS IN AVERAGE MEASUREMENTS BETWEEN 1913-14 AND 1953-54

\begin{tabular}{|c|c|c|c|c|c|}
\hline \multirow{2}{*}{ City } & \multirow{2}{*}{$\begin{array}{c}\text { Agge } \\
\text { (yrs) }\end{array}$} & \multicolumn{2}{|c|}{ Boys } & \multicolumn{2}{|c|}{ Girls } \\
\hline & & $\begin{array}{l}\text { Height } \\
\text { (in.) }\end{array}$ & $\begin{array}{c}\text { Weight } \\
\text { (lb.) }\end{array}$ & $\begin{array}{l}\text { Height } \\
\text { (in.) }\end{array}$ & $\begin{array}{c}\text { Weight } \\
\text { (lb.) }\end{array}$ \\
\hline Edinburgh & $\begin{array}{r}5 \\
9 \\
13\end{array}$ & $\underset{3 \frac{1}{2}}{1 \frac{1}{2}} \mathbf{3}$ & $\begin{array}{c}2 \\
7 \frac{1}{2} \\
14 \frac{1}{4}\end{array}$ & $\begin{array}{c}1 \\
2 \frac{1}{2} \\
\text { Nearly } 3\end{array}$ & $\begin{array}{r}1 \frac{1}{7} \\
12 \frac{1}{2}\end{array}$ \\
\hline Glasgow & $\begin{array}{r}5 \\
9 \\
13\end{array}$ & $\begin{array}{c}\text { Nearly } 2 \\
4 \\
\text { Nearly } 4\end{array}$ & $\begin{array}{r}4 t \\
8 \frac{1}{2} \\
14 \frac{1}{2}\end{array}$ & $\begin{array}{c}\frac{1 \frac{1}{2}}{2} \\
\text { Nearly } \\
3 t\end{array}$ & $\begin{array}{c}3 \frac{1}{2} \\
7 \\
16 \frac{1}{2}\end{array}$ \\
\hline
\end{tabular}

(b) As may be seen from Appendix Table A, the average heights and weights of Edinburgh schoolchildren of the various age groups in 1913-14 were all greater than those of the Glasgow schoolchildren of corresponding age, but as the years have passed there has been a progressive closure of the "gaps" in most instances. Thus, for 1953-54, the average measurements of the Edinburgh children are greater:

For boys:

by 0.36 in. and $0.62 \mathrm{lb}$. at 5 years, by $0.32 \mathrm{in}$. and $0.89 \mathrm{lb}$. at 9 years, by $0.56 \mathrm{in}$. and $2.34 \mathrm{lb}$. at 13 years; For girls:

by 0.24 in. and $0.21 \mathrm{lb}$. at 5 years, by $0.17 \mathrm{in}$. and $1.81 \mathrm{lb}$. at 9 years, by 0.37 in. and $1.57 \mathrm{lb}$. at 13 years. 
Despite the progressive closure of the "gaps" between the average measurements of the children of the two cities, as many as eleven of the twelve differences are still of statistical significance (the difference being at least three times its respective standard error in ten instances, and $2 \cdot 2$ times its standard error in the remaining instance, that relating to the height of 9-year-old girls); the difference which is not of statistical significance is that in respect of the weight of 5-year-old girls.

It is not without interest to find, on studying the measurements of the Glasgow schoolchildren for the past 15 years, that the proportionate increases in average height and weight between 5 and 9 years, 9 and 13 years, and 5 and 13 years, are more or less identical for children born in 1925 and in subsequent years up to and including 1940 (these increases being greater, of course, for girls than for boys between 9 and 13 years, and 5 and 13 years.) These proportionate increases are set out in Table III:

TABLE III

CITY OF GLASGOW

CHILDREN BORN IN 1925 AND IN SUBSEQUENT YEARS PERCENTAGE INCREASES IN AVERAGE MEASUREMENTS

\begin{tabular}{|c|c|c|c|c|}
\hline \multirow{2}{*}{ Period (yrs) } & \multicolumn{2}{|c|}{ Boys } & \multicolumn{2}{|c|}{ Girls } \\
\hline & Height & Weight & Height & Weight \\
\hline $\begin{array}{l}5-9 \\
9-13 \\
5-13\end{array}$ & $\begin{array}{l}21 \cdot 5 \\
15 \cdot 5 \\
40 \cdot 0\end{array}$ & $\begin{array}{r}47 \cdot 0 \\
46 \cdot 0 \\
115 \cdot 0\end{array}$ & $\begin{array}{l}21 \cdot 0 \\
17 \cdot 5 \\
43 \cdot 0\end{array}$ & $\begin{array}{r}48 \cdot 0 \\
58 \cdot 0 \\
135 \cdot 0\end{array}$ \\
\hline
\end{tabular}

This position arises directly from the fact that for Glasgow schoolchildren in the past $\mathbf{1 5}$ years, as for London schoolchildren during the period 1938-49 (Daley, 1950), the change in weight has been proportionate to the change in height, with the result that the ratio of weight to height has remained more or less steady. The report on the London investigations summarized the position thus:

The fact that bone and flesh have kept pace with each other, despite substantial changes in the absolute values of height and weight, suggests that with improved nutrition in schoolchildren, nature has maintained her own balance; that children of to-day are not merely heavier or merely taller than their parents were, but are members of a generation altogether of greater physique.

In the report on the London investigation, use was made of the metric system in calculating the weight to height ratio, and for 1938 and 1949 alike, the ratio of average height $(\mathrm{cm}$.) to average weight (kg.) was as follows:

$$
\begin{aligned}
& \text { For boys: } \\
& 0.17 \text { at } 5 \text { years, } \\
& 0.21 \text { at } 9 \text { years, } \\
& 0.27 \text { at } 13 \text { years. } \\
& \text { For girls: } \\
& 0.17 \text { at } 5 \text { years, } \\
& 0.21 \text { at } 9 \text { years, } \\
& 0.28 \text { at } 13 \text { years. }
\end{aligned}
$$

For the Glasgow schoolchildren, the corresponding values-which have varied only slightly throughout the 15-year period-are set out in Table IV:

TABLE IV

RATIO OF AVERAGE HEIGHT (cm.) TO AVERAGE WEIGHT (kg.) OF GLASGOW .SCHOOLCHILDREN (1938-54)

\begin{tabular}{c|c|c}
\hline Age (yrs) & Boys & Girls \\
\hline 5 & $0 \cdot 175$ & $0 \cdot 170$ \\
9 & $0 \cdot 215$ & $0 \cdot 210$ \\
13 & $0 \cdot 270$ & $0 \cdot 280$ \\
\hline
\end{tabular}

(2) Edinburgh, Glasgow, Dundee, and AyrSHIRE: MEAN HEIGHTS AND WeIGHTS OF ChILdRen AGEd 5, 9, 13, AND 16 YeARS ATTENDing Education Authority Schools, Sessions 1948-49 TO 1953-54.

Appendix Table B shows the average heights and weights of the boys and girls measured at the time of systematic medical examination in these four areas. The actual measurements have been adjusted, however, to the uniform ages of $5 \frac{4}{1 \frac{1}{2}}, 9 \frac{6}{12}, 13 \frac{6}{12}$, and $16 \frac{7}{1^{2}}$ years. For the 5, 9, and 13-year-olds, use is made of the factors employed in recent years in Glasgow in adjusting the average measurements of children of these ages. For the 16-year-olds, the corresponding factors for the Edinburgh children are used, since these are even more up-to-date (being based on the results of personal investigations concerning the measurements of pupils of this age during the three school sessions, 1951-52 to 1953-54).

Concern here is primarily with two related questions-on comparing the figures for 1953-54, first with those for 1948-49, and secondly with those for 1952-53, are the differences in average heights and weights of statistical significance?

As to the comparison of the figures for 1953-54 with those for 1948-49, Table V (upper half) summarizes the relevant particulars from Appendix Table B, and shows the differences for each age group in respect of height and weight, and the amount by which each difference is greater than its standard error. All these sixteen differences favour session 1953-54 and all are of statistical significance.

In like fashion, Table $\mathrm{V}$ (lower half) summarizes the essential points for the two sessions, 1952-53 and 1953-54.

For the boys, all the eight differences except one favour session 1953-54; the difference is at least three times its standard error in six instances, only that relating to the height of the 16-year-olds not being of statistical significance. Exceptionally, the average weight of the 5-year-olds in 1952-53 is 
TABLE $V$

CITIES OF EDINBURGH, GLASGOW, AND DUNDEE, AND COUNTY OF AYRSHIRE MEAN HEIGHTS AND WEIGHTS AT 5\%, 9\%, 13\%, AND 16\%, YRS COMPARISON OF FIGURES FOR 1953-54 WITH THOSE FOR 1948-49 AND 1952-53

\begin{tabular}{|c|c|c|c|c|c|c|c|c|c|}
\hline \multirow{3}{*}{ Sex } & \multirow{3}{*}{ Session } & \multicolumn{8}{|c|}{ Age (yrs) } \\
\hline & & \multicolumn{2}{|c|}{5} & \multicolumn{2}{|c|}{9} & \multicolumn{2}{|c|}{13} & \multicolumn{2}{|c|}{16} \\
\hline & & $\begin{array}{l}\text { Height } \\
\text { (in.) }\end{array}$ & $\begin{array}{l}\text { Weight } \\
\text { (lb.) }\end{array}$ & $\begin{array}{l}\text { Height } \\
\text { (in.) }\end{array}$ & $\begin{array}{l}\text { Weight } \\
\text { (lb.) }\end{array}$ & $\begin{array}{l}\text { Height } \\
\text { (in.) }\end{array}$ & $\begin{array}{l}\text { Weight } \\
\text { (lb.) }\end{array}$ & $\begin{array}{l}\text { Height } \\
\text { (in.) }\end{array}$ & $\begin{array}{l}\text { Weight } \\
\text { (1b.) }\end{array}$ \\
\hline \multirow{3}{*}{ Boys } & $1948-49$ & $42 \cdot 65$ & $42 \cdot 36$ & $51 \cdot 69$ & $63 \cdot 49$ & $59 \cdot 00$ & $90 \cdot 01$ & $66 \cdot 86$ & $130 \cdot 60$ \\
\hline & $1953-54$ & $42 \cdot 73$ & $42 \cdot 54$ & $51 \cdot 82$ & 64.09 & $59 \cdot 56$ & $93 \cdot 37$ & $67 \cdot 64$ & $134 \cdot 48$ \\
\hline & $\begin{array}{r}\text { Difference } \\
t=\end{array}$ & $\begin{array}{l}0.08 \\
3.9\end{array}$ & $\begin{array}{l}0 \cdot 18 \\
3 \cdot 6\end{array}$ & $\begin{array}{l}0 \cdot 13 \\
4 \cdot 2\end{array}$ & $\begin{array}{l}0.60 \\
5.6\end{array}$ & $\begin{array}{c}0.56 \\
12 \cdot 8\end{array}$ & $\begin{array}{c}3 \cdot 36 \\
15 \cdot 1\end{array}$ & $\begin{array}{r}0 \cdot 78 \\
7 \cdot 3\end{array}$ & $\begin{array}{l}3 \cdot 88 \\
5 \cdot 7\end{array}$ \\
\hline \multirow{3}{*}{ Girls } & $1948-49$ & $42 \cdot 19$ & $40 \cdot 69$ & $51 \cdot 04$ & $60 \cdot 72$ & $59 \cdot 35$ & $94 \cdot 22$ & $63 \cdot 49$ & $121 \cdot 24$ \\
\hline & $1953-54$ & $42 \cdot 48$ & $41 \cdot 10$ & $51 \cdot 34$ & $62 \cdot 45$ & 59.96 & $97 \cdot 37$ & $63 \cdot 63$ & $122 \cdot 81$ \\
\hline & $\begin{array}{r}\text { Difference } \\
t=\end{array}$ & $\begin{array}{l}0 \cdot 29 \\
13 \cdot 8\end{array}$ & $\begin{array}{l}0 \cdot 41 \\
7 \cdot 8\end{array}$ & $\begin{array}{l}0.30 \\
9 \cdot 5\end{array}$ & $\begin{array}{c}1 \cdot 73 \\
14 \cdot 4\end{array}$ & $\begin{array}{c}0 \cdot 61 \\
16 \cdot 6\end{array}$ & $\begin{array}{c}3 \cdot 15 \\
14 \cdot 7\end{array}$ & $\begin{array}{l}0 \cdot 14 \\
4 \cdot 5\end{array}$ & $\begin{array}{l}1 \cdot 57 \\
2 \cdot 1\end{array}$ \\
\hline \multirow{3}{*}{ Boys } & $1952-53$ & $42 \cdot 65$ & $42 \cdot 61$ & $51 \cdot 55$ & $63 \cdot 29$ & $59 \cdot 40$ & $92 \cdot 68$ & $67 \cdot 55$ & $132 \cdot 39$ \\
\hline & $1953-54$ & $42 \cdot 73$ & $42 \cdot 54$ & $51 \cdot 82$ & $64 \cdot 09$ & $59 \cdot 56$ & $93 \cdot 37$ & $67 \cdot 64$ & $134 \cdot 48$ \\
\hline & $\begin{array}{r}\text { Difference } \\
t=\end{array}$ & $\begin{array}{l}0 \cdot 08 \\
4 \cdot 1\end{array}$ & $\begin{array}{l}0 \cdot 07 \\
1 \cdot 4\end{array}$ & $\begin{array}{l}0 \cdot 27 \\
8 \cdot 9\end{array}$ & $\begin{array}{l}0 \cdot 80 \\
7 \cdot 5\end{array}$ & $\begin{array}{l}0 \cdot 16 \\
3 \cdot 7\end{array}$ & $\begin{array}{l}0 \cdot 69 \\
3 \cdot 1\end{array}$ & $\begin{array}{l}0.09 \\
0.8\end{array}$ & $\begin{array}{l}2 \cdot 09 \\
3 \cdot 1\end{array}$ \\
\hline \multirow{3}{*}{ Girls } & $1952-53$ & $42 \cdot 34$ & 40.96 & $51 \cdot 30$ & $61 \cdot 60$ & $59 \cdot 84$ & $96 \cdot 72$ & $63 \cdot 64$ & $122 \cdot 70$ \\
\hline & 1953-54 & $42 \cdot 48$ & $41 \cdot 10$ & $51 \cdot 34$ & $62 \cdot 45$ & $59 \cdot 96$ & $97 \cdot 37$ & $63 \cdot 63$ & $122 \cdot 81$ \\
\hline & $\begin{array}{r}\text { Difference } \\
t=\end{array}$ & $\begin{array}{l}0.14 \\
7 \cdot 0\end{array}$ & $\begin{array}{l}0 \cdot 14 \\
2 \cdot 8\end{array}$ & $\begin{array}{l}0 \cdot 04 \\
1 \cdot 1\end{array}$ & $\begin{array}{l}0.85 \\
7 \cdot 1\end{array}$ & $\begin{array}{l}0 \cdot 12 \\
3 \cdot 3\end{array}$ & $\begin{array}{l}0.65 \\
3.0\end{array}$ & $\begin{array}{l}0.01 \\
0.1\end{array}$ & $\begin{array}{l}0.11 \\
1 \cdot 5\end{array}$ \\
\hline
\end{tabular}

above that of those in 1953-54 but the difference is not statistically significant.

For the girls, seven of the eight differences favour 1953-54; five are significant, the difference being at least three times its standard error in four instances, and $2 \cdot 8$ times in the fifth, and two relating to the height of the 9 and 16-year-olds are not significant. The difference in respect of the weight of the 16-year-olds (which alone favours 1952-53) is not of statistical significance.

These results, in conjunction with those arising from the comparison of the figures for 1953-54 with those for 1948-49, show unmistakably a continuance, among children of school age, of the upward trend in average heights and weights that has been a noteworthy feature of the past two decades.

(3) Regional Analysis: Mean Heights and Weights OF CHILDREN AGED 5, 9, 13, AND 16 YEARS, ATTENDING SCOTTISH EDUCATION AUthority SchOOLS, SESSIONS 1951-52 AND 1952-53.

A few years ago, a regional analysis of the average heights and weights of the children of the age groups customarily dealt with at systematic medical examinations gave somewhat anomalous results. This was due, it was believed, to the failure in certain areas, in the years immediately after the end of the recent war, to provide a proper system of checking the accuracy of the weighing machines and to make adequate provision for servicing them. Steps have been taken, however, by the authorities concerned to replace outmoded machines and to provide a regular system of checking and servicing, so that the results can now be accepted with a reasonable degree of assurance. This is so, despite the fact that, though the common practice, as in Edinburgh and Glasgow, is for the children to be weighed without shoes and wearing underpants (boys) or vests and knickers (girls), the children in certain areas wear slightly more clothing. Such a variation, however, does not invalidate the results for the country as a whole or for any of the six regions into which Scotland is divided for the purpose of the present analysis. The usual practice is to record the height to the nearest quarter of an inch, and the weight to the nearest quarter (or half) pound, using a steelyard weighing machine and fixed height-measuring equipment (in the absence of a height-measuring attachment to the machine). The height is taken with the child standing erect, back to the measuring rod, with the feet together and the weight on the heels and not on the toes or the outside of the feet. 
A geographical-industrial grouping as been adopted for the regional analysis of the average heights and weights of the children aged 5,9,13, and 16 years. The six broad groups are as follows:

Region 1.-Highlands, comprising the northern and western counties, Aberdeen (excluding the city of Aberdeen), Argyll, Bute, Caithness, Inverness, Moray, Nairn, Orkney, Perth (and Kinross), Ross and Cromarty, Sutherland, and Zetland. Half of these are mainly rural areas, and the other half mainly consist of heath and moor.

Region 2.-Eastern Counties, comprising the counties of Angus (excluding Dundee), Banff, Clackmannan, Fife, and Kincardine. This region is predominantly rural, but has extensive fishing interests and, in the south-west of Fife, a considerable industrial and coal-mining population.

Region 3.-Cities of Edinburgh, Aberdeen, and Dundee. These urban districts are of a less industrial and more residential character than Region 6.

Region 4.-Southern Counties, comprising the lowland counties of Ayr, Berwick, Dumfries, East Lothian, Kirkcudbright, Midlothian (excluding Edinburgh), Peebles, Roxburgh, Selkirk, and Wigtown. Mainly rural, the region also contains many centres of light industry and, in Ayr, East Lothian, and Midlothian, extensive coal-mining interests.

Region 5.-Western and Central Industrial Areas, comprising the counties of Dunbarton, Lanark (excluding Glasgow), Renfrew, Stirling, and West Lothian. Primarily industrial-the heavy industries predominating, on balance-the region also contains a number of important coal-mining centres, and, as in Lanark and Stirling, extensive agricultural districts.

Region 6.-City of Glasgow. This is the most highly industrial of the four main cities of Scotland.

This grouping is on lines akin to those followed by Martin (1949) in his analysis of the medical examinations of 20-year-old Scotsmen registered under the Military Training Act, 1939, but there are a few important differences. Regions 1, 2, and 3 are more or less identical in both instances, but in the present article the region "Glasgow, Motherwell, Paisley" (representative of the more highly industrialized towns) is replaced by "Region 6, City of Glasgow" and "Region 7, Western and Central Industrial Area"; the counties of Dunbarton, Lanark, Stirling, and West Lothian are thus separated from the "Southern Counties" of the M.R.C. Memorandum.

In the present analysis a distinction is drawn between the children aged 5,9 , and 13 years on the one hand, and those aged 16 years on the other. Children aged 5, 9, and 13 years attending education authority schools constitute a high proportion of all the children of these age groups in each of the six regions (those at fee-paying schools independent of education authorities, for example, forming a very small proportion of the total), but the 16-year-old pupils at education authority schools do not form in any of the regions a representative cross-section of the children of that age group in the community.

Personal study of the particulars given on large numbers of medical record cards shows clearly that about two-thirds of the fathers of pupils who continue in attendance at secondary schools to the age of 16 years and beyond are in Social Classes I or II or in the more highly-skilled occupations of Social Class III.* This aspect of the subject needs no emphasis, as it has recently been dealt with at length by the Scottish Mental Survey Committee (Scottish Council for Research in Education, 1953) and the Central Advisory Council for Education (Ministry of Education, 1954). The essential point, for present purposes, is that, in arranging the six regions in descending order of average heights and weights, our prime concern is with the measurements of the 5, 9, and 13-year-olds.

Appendix Tables C and D show the average heights and weights of children of these three age groups for the two sessions 1951-52 and 1952-53, for each of the six regions as well as for Scotland as a whole. The actual average measurements have been adjusted to the uniform ages of $5 \frac{4}{12}, 9 \frac{6}{12}$, and $13 \frac{6}{12}$ years-the most convenient and appropriate in this instance-by use of the factors derived from a study of the measurements of children attending education authority schools in Edinburgh in session 1952-53.

The numbers dealt with are large, those for boys in Scotland as a whole totalling 44,936 at 5 years, 32,931 at 9 years, and 30,798 at 13 years in 1952-53, the corresponding totals for girls being 43,030, 31,828 , and 30,108 , respectively. In the six regions, the totals range for boys from 5,018 to 11,901 at 5 years, from 3,199 to 9,725 at 9 years, and from 3,161 to 8,454 at 13 years; the corresponding figures for girls are of like magnitude, and for them as for the boys, the lowest regional total for each age group is that for the Eastern Counties (Region 2), and the highest that for the Western and Central Industrial Area (Region 5).

\footnotetext{
* The five social classes are those into which occupations are customarily grouped in vital statistical investigations (General Register Office, 1951).
} 
TABLE VI

SIX SCOTTISH REGIONS ARRANGED IN DESCENDING ORDER OF MEAN HEIGHTS AND WEIGHTS

\begin{tabular}{|c|c|c|c|c|c|c|c|c|c|c|c|c|c|c|}
\hline \multirow{3}{*}{$\begin{array}{l}\frac{\text { Age (yrs) }}{\text { Measurement }} \\
\text { Session ... }\end{array}$} & \multirow{3}{*}{$\begin{array}{l}\cdots \\
\cdots \\
\cdots\end{array}$} & \multirow{3}{*}{$\frac{\cdots}{\cdots}$} & \multicolumn{4}{|c|}{5} & \multicolumn{4}{|c|}{9} & \multicolumn{4}{|c|}{13} \\
\hline & & & \multicolumn{2}{|c|}{ Height } & \multicolumn{2}{|c|}{ Weight } & \multicolumn{2}{|c|}{ Height } & \multicolumn{2}{|c|}{ Weight } & \multicolumn{2}{|c|}{ Height } & \multicolumn{2}{|c|}{ Weight } \\
\hline & & & $1951-2$ & $1952-3$ & $1951-2$ & $1952-3$ & $1951-2$ & $1952-3$ & $1951-2$ & $1952-3$ & $1951-2$ & $1952-3$ & $1951-2$ & $1952-3$ \\
\hline Boys & $\therefore$ & . & $\begin{array}{l}1 \\
4 \\
5 \\
2 \\
3 \\
6\end{array}$ & $\begin{array}{l}1 \\
2 \\
4 \\
5 \\
3 \\
6\end{array}$ & $\begin{array}{l}1 \\
4 \\
5 \\
3 \\
2 \\
6\end{array}$ & $\begin{array}{l}1 \\
4 \\
5 \\
2 \\
3 \\
6\end{array}$ & $\begin{array}{l}4 \\
1 \\
5 \\
2 \\
3 \\
6\end{array}$ & $\begin{array}{l}1 \\
4 \\
5 \\
2 \\
6 \\
3\end{array}$ & $\begin{array}{l}1 \\
4 \\
2 \\
5 \\
3 \\
6\end{array}$ & $\begin{array}{l}1 \\
4 \\
2 \\
5 \\
3 \\
6\end{array}$ & $\begin{array}{l}4 \\
1 \\
2 \\
3 \\
5 \\
6\end{array}$ & $\begin{array}{l}2 \\
4 \\
1 \\
3 \\
5 \\
6\end{array}$ & $\begin{array}{l}1 \\
4 \\
2 \\
5 \\
3 \\
6\end{array}$ & $\begin{array}{l}1 \\
4 \\
3 \\
5 \\
2 \\
6\end{array}$ \\
\hline Girls . . & . & . & $\begin{array}{l}4 \\
2 \\
1 \\
5 \\
3 \\
6\end{array}$ & $\begin{array}{l}1 \\
4 \\
5 \\
2 \\
3 \\
6\end{array}$ & $\begin{array}{l}1 \\
4 \\
2 \\
5 \\
3 \\
6\end{array}$ & $\begin{array}{l}1 \\
4 \\
2 \\
5 \\
3 \\
6\end{array}$ & $\begin{array}{l}1 \\
4 \\
2 \\
5 \\
3 \\
6\end{array}$ & $\begin{array}{l}1 \\
4 \\
2 \\
5 \\
3 \\
6\end{array}$ & $\begin{array}{l}1 \\
2 \\
4 \\
3 \\
5 \\
6\end{array}$ & $\begin{array}{l}1 \\
4 \\
2 \\
3 \\
5 \\
6\end{array}$ & $\begin{array}{l}2 \\
4 \\
1 \\
3 \\
5 \\
6\end{array}$ & $\begin{array}{l}4 \\
1 \\
5 \\
3 \\
2 \\
6\end{array}$ & $\begin{array}{l}4 \\
1 \\
2 \\
3 \\
5 \\
6\end{array}$ & $\begin{array}{l}1 \\
4 \\
3 \\
2 \\
5 \\
6\end{array}$ \\
\hline
\end{tabular}

In Table VI the regions are arranged in descending order of average height and weight.

For boys, Region 1 (Highlands) and Region 4 (Southern Counties)-commonly in that orderalmost invariably occupy the two top positions, and have the highest average values for both height and weight. Region 6 (Glasgow) occupies the lowest positions for height, with one exception, and weight, and Region 3 (Edinburgh, Aberdeen, and Dundee) most commonly occupies the second lowest position for both height and weight. Region 2 (Eastern Counties) and Region 5 (Western and Central Industrial Region) are intermediate, Region 2 being slightly superior to Region 5 in respect of height, while in weight, on balance, there is equality.

For girls, the pattern is practically identical. Regions 1 and 4 almost invariably have the highest average heights and weights-with Region 1 usually top, Region 6 invariably bottom, and Region 3 usually second to bottom. Here also Regions 2 and 5 occupy intermediate positions, with Region 2 usually above Region 5 in both height and weight.

Moreover, for each of the two sessions and for boys and girls alike, the order of the average weights of a particular age group is nearly always either identical with, or very close to, the order of the average heights.

As to the significance or otherwise of these various differences in average height and average weight, it is proposed to make seven sets of comparisons:

(a) Comparison of All-Scotland Mean Heights and Weights, 1951-52 and 1952-53.-Table VII summarizes the average heights and weights for Scotland as a whole for each of the two sessions, and shows the differences and the amount by which each exceeds its standard error.
TABLE VII

SCOTTISH EDUCATION AUTHORITY SCHOOLS MEAN HEIGHTS AND WEIGHTS OF CHILDREN AGED 5\%, 9\%, AND 13\%, YEARS

ALL-SCOTLAND MEANS, 1951-52 AND 1952-53

\begin{tabular}{|c|c|c|c|c|c|c|c|}
\hline \multirow{2}{*}{\multicolumn{2}{|c|}{$\begin{array}{l}\text { Age (yrs) } \\
\text { Measurement }\end{array}$}} & \multicolumn{2}{|c|}{5} & \multicolumn{2}{|c|}{9} & \multicolumn{2}{|c|}{13} \\
\hline & & \multirow{2}{*}{\begin{tabular}{|c|}
$\begin{array}{c}\text { Height } \\
\text { (in.) }\end{array}$ \\
$42 \cdot 93$ \\
\end{tabular}} & \multirow{2}{*}{\begin{tabular}{|c|}
$\begin{array}{c}\text { Weight } \\
\text { (lb.) }\end{array}$ \\
$43 \cdot 13$
\end{tabular}} & \multirow{2}{*}{\begin{tabular}{|c|}
$\begin{array}{c}\text { Height } \\
\text { (in.) }\end{array}$ \\
51.98 \\
\end{tabular}} & \multirow{2}{*}{\begin{tabular}{|c|}
$\begin{array}{c}\text { Weight } \\
\text { (lb.) }\end{array}$ \\
$64 \cdot 14$ \\
\end{tabular}} & \multirow{2}{*}{\begin{tabular}{|c|}
$\begin{array}{c}\text { Height } \\
\text { (in.) }\end{array}$ \\
59.97 \\
\end{tabular}} & \multirow{2}{*}{\begin{tabular}{|c|}
$\begin{array}{c}\text { Weight } \\
\text { (lb.) }\end{array}$ \\
$92 \cdot 87$
\end{tabular}} \\
\hline \multirow{3}{*}{ Boys } & 1951-52 & & & & & & \\
\hline & $1952-53$ & $43 \cdot 00$ & $43 \cdot 12$ & 51.93 & $64 \cdot 27$ & $59 \cdot 52$ & $93 \cdot 52$ \\
\hline & $\begin{array}{c}\text { Difference } \\
t=\end{array}$ & $\begin{array}{l}0.07 \\
5 \cdot 7\end{array}$ & $\begin{array}{l}0.01 \\
0.3\end{array}$ & $\begin{array}{l}0.05 \\
2.8\end{array}$ & $\begin{array}{l}0.13 \\
1.9\end{array}$ & $\begin{array}{l}0.05 \\
1.8\end{array}$ & $\begin{array}{l}0.65 \\
4 \cdot 7\end{array}$ \\
\hline \multirow{3}{*}{ Girls } & $1951-52$ & $42 \cdot 53$ & 41.47 & $51 \cdot 48$ & $61 \cdot 66$ & $60 \cdot 12$ & 97.67 \\
\hline & $1952-53$ & $42 \cdot 61$ & $41 \cdot 50$ & $51 \cdot 54$ & $62 \cdot 04$ & $59 \cdot 99$ & $97 \cdot 53$ \\
\hline & $\begin{array}{c}\text { Difference } \\
t=\end{array}$ & $\begin{array}{l}0.08 \\
6.2\end{array}$ & $\begin{array}{l}0.03 \\
0.9\end{array}$ & $\begin{array}{l}0.06 \\
2.7\end{array}$ & $\begin{array}{l}0.38 \\
5.0\end{array}$ & $\begin{array}{l}0.13 \\
5.5\end{array}$ & $\begin{array}{l}0.14 \\
1.0\end{array}$ \\
\hline
\end{tabular}

Three of the six differences for boys are significant:

(i) the increase in average height at 5 years,

(ii) the increase in average weight at 13 years,

(iii) the fall in average height at 9 years.

Four of the six differences for girls are significant:

(i) the increase in average height at 5 years,

(ii) the increase in average height at 9 years,

(iii) the fall in average height at 13 years,

(iv) the increase in average weight at 9 years.

These facts, although in respect of two consecutive years only, provide additional evidence, on balance, that the upward trend in the average heights and weights of schoolchildren that has characterized the past two decades is continuing.

(b) Comparison of Mean Heights and Weights for Individual Regions with those for Scotland as a Whole, 1951-52 and 1952-53.-As an indication of the extent to which some of the average heights and weights for the individual regions differ from those 
for Scotland as a whole, the range for each age group for 1952-53 is shown in Table VIII.

TABLE VIII

SCOTTISH EDUCATION AUTHORITY SCHOOLCHILDREN REGIONAL ANALYSIS OF MEAN HEIGHTS AND WEIGHTS RANGE OF MEASUREMENTS AT $5 \% 12,9 \% 12$, AND $13 \%$ YEARS 1952-53

\begin{tabular}{|c|c|c|c|c|}
\hline \multirow[b]{2}{*}{ Age (yrs) } & \multicolumn{2}{|c|}{ Boys } & \multicolumn{2}{|c|}{ Girls } \\
\hline & $\begin{array}{l}\text { Height } \\
\text { (in.) }\end{array}$ & $\begin{array}{c}\text { Weight } \\
\text { (lb.) }\end{array}$ & $\begin{array}{c}\text { Height } \\
\text { (in.) }\end{array}$ & $\begin{array}{c}\text { Weight } \\
\text { (lb.) }\end{array}$ \\
\hline 5 & $42 \cdot 48-43 \cdot 53$ & $42 \cdot 07-44 \cdot 59$ & $42 \cdot 16-43 \cdot 09$ & $40 \cdot 54-43 \cdot 07$ \\
\hline 9 & $51 \cdot 26-52 \cdot 51$ & $62 \cdot 59-66 \cdot 75$ & $50 \cdot 90-52 \cdot 47$ & $60 \cdot 73-64 \cdot 44$ \\
\hline 13 & $59 \cdot 15-60 \cdot 21$ & $91 \cdot 11-98 \cdot 21$ & $59 \cdot 51-60 \cdot 56$ & $95 \cdot 20-100 \cdot 37$ \\
\hline
\end{tabular}

The results for 1951-52 and 1952-53 are remarkably consistent for both girls and boys, for Regions 1 and 4 on the one hand, and Regions 6 and 3 . on the other. There is justification for the conclusion that at 5,9 , and 13 years the average measurements of the children in Regions 1 and 4 are above the corresponding all-Scotland averages, the differences for boys being invariably, and those for girls almost invariably, of statistical significance:

Regions 1 and 4:

Boys: height, $t=4.5$ or more; weight, $t=3.5$ or more.

Girls: height, $t=5 \cdot 5$ or more as a rule; weight, $t=7 \cdot 3$ or more.

Moreover, at those ages, the average measurements of the children in Regions 6 and 3 are below the corresponding all-Scotland averages, the differences for Region 6 being invariably, and those for Region 3 almost invariably, of statistical significance:

Region 6:

Boys: height, $t=12$ or more; weight, $t=9 \cdot 9$ or more.

Girls: height, $t=9 \cdot 7$ or more; weight, $t=10$ or more.

(c) Comparison of Mean Heights and Weights for Region 1 (Highlands) with those for Region 4 (Southern Counties), 1951-52 and 1952-53.-An analysis, in terms of the significance or otherwise of the differences between the average heights and weights of the children of Region 1 and those of Region 4, at 5, 9, and 13 years, gives the following results:

Boys.-For the two sessions as a whole, there is a high proportion of differences which are not of statistical significance; the only significant differences common to both sessions are those at 5 years in respect of height $(t=3 \cdot 2$ and 5.4), which favour Region 1 in each instance.
Girls.-There are four significant differences common to both sessions. For Region 1 there are significantly higher averages at 5 years in respect of weight $(t=13$ and 11), and at 9 years in respect of both height $(t=3$ and $7 \cdot 8)$ and weight $(t=6 \cdot 3$ and $5 \cdot 1)$. Region 4 has significantly higher averages at 13 years in respect of height $(t=3 \cdot 6$ and $7 \cdot 9)$.

(d) Comparison of Mean Heights and Weights for Regions 1 and 4 with those for Other Regions, 1951-52 and 1952-53.-Attention is here confined to two points. First, there is a comparison, for each age group, of the average measurements for Regions 1 and 4 with the corresponding averages for the region providing the next highest average. Secondly, in the exceptional cases in which the average of the third region is higher than that of Region 1 and/or Region 4, there is the question of whether or not the difference is significant.

For boys and girls alike it is found that, when Region 1 and Region 4 present the highest and the second highest averages (as is usually the case, in respect of both height and weight), these averages almost invariably exceed to a significant extent the next highest corresponding average; when, exceptionally, the average for a region other than Region 1 or Region 4 is the highest for a particular age group, that average is most commonly not significantly greater than the corresponding averages for Regions 1 and 4.

(e) Comparison of Mean Heights and Weights for Region 6 (Glasgow) with those for Region 3 (Edinburgh, Aberdeen, and Dundee), 1951-52 and 1952-53. -The results of this analysis are as follows:

Height.-Over the two sessions as a whole, there are two instances only in which the averages for Region 6 exceed those for Region 3, namely, the averages in 1952-53 for boys aged 5 years (although the difference is not of statistical significance) and 9 years $(t=5 \cdot 2)$.

In the remaining four instances among boys, and in all six instances among girls, the average heights for Region 6 are significantly below those for Region 3 ( $t=4$ or more, except in one case).

Weight.-For both boys and girls, the averages for Region 6, for all three age groups in both sessions, are significantly below the corresponding averages for Region 3 ( $t=4 \cdot 7$ or more).

(f) Comparison of Regions in Descending Order of Mean Heights and Weights with the Regional Order of Means for Young Adult Scotsmen examined under - the Military Training Act, 1939.--Brief reference has already been made to the Medical Research Council's memorandum (Martin, 1949) analysing the findings concerning 91,513 men aged 20 years (9,620 of them Scotsmen) who registered under the Military Training Act, 1939. The analysis was 
restricted to those examined before the outbreak of war, and despite the absence of farm workers, the group represented not unfairly the young adult male population of the country at that time.

Table IX shows the main findings for the 9,620 20-year-old Scotsmen, the regions being arranged in descending order of average heights and weights.

TABLE IX

YOUNG ADULT SCOTSMEN REGISTERED UNDER MILITARY TRAINING ACT, 1939

MEAN HEIGHTS AND WEIGHTS, BY REGION

\begin{tabular}{|c|c|c|c|}
\hline \multirow[b]{2}{*}{ Region } & \multirow[b]{2}{*}{$\begin{array}{l}\text { Approx. } \\
\text { No. } \\
\text { Examined }\end{array}$} & - Height (in.) & Weight (lb.) \\
\hline & & $\begin{array}{l}\text { Mean } \\
\text { Height } \pm \text { S.E. S.D. }\end{array}$ & Mean ${ }_{\text {Weight } \pm \text { S.E. S.D. }}$ \\
\hline Highlands & 510 & $67.8 \pm 0.112 .53$ & $142 \cdot 3 \pm 0.7517 .03$ \\
\hline $\begin{array}{l}\text { Eastern } \\
\text { Counties }\end{array}$ & 1,070 & $67.3 \pm 0.08 \quad 2.49$ & $138 \cdot 3 \pm 0.48 \quad 15 \cdot 79$ \\
\hline $\begin{array}{l}\text { Edinburgh, } \\
\text { Aberdeen, } \\
\text { and Dundee }\end{array}$ & 1,570 & $67.1 \pm 0.072 .61$ & $135.9 \pm 0.38 \quad 15.08$ \\
\hline $\begin{array}{l}\text { Southern } \\
\text { Counties }\end{array}$ & 2,620 & $67.1 \pm 0.052 .55$ & $135.7 \pm 0.31 \quad 15.68$ \\
\hline $\begin{array}{l}\text { Glasgow, } \\
\text { Motherwell, } \\
\text { and Paisley }\end{array}$ & 3,850 & $66.7 \pm 0.042 .65$ & $133 \cdot 1 \pm 0.25 \quad 15.55$ \\
\hline $\begin{array}{l}\text { All } \\
\text { Scotland }\end{array}$ & 9,620 & $67.0 \pm 0.03 \quad 2.61$ & $135 \cdot 3 \pm 0.1615 .91$ \\
\hline
\end{tabular}

As Martin pointed out, the highlanders were on the average superior in physical measurements, the average height ranging from 0.4 to $1.1 \mathrm{in}$. and the average weight from 4.0 to $9 \cdot 2 \mathrm{lb}$. above those of men from the other regions; men from the industrial centres of Glasgow, Motherwell, and Paisley, on the other hand, were inferior to those from the other regions in average height and weight, being, for example, 0.6 in. shorter and slightly more than $2 \frac{1}{2} \mathrm{lb}$. lighter than those from the two regions with the next smallest averages (namely, the Southern Counties-which in that investigation included several counties with highly industrial centres-and the cities of Edinburgh, Aberdeen, and Dundee).

The results of the particular part of the present investigation that is used for comparison with the above tally closely with the latter in respect of the regional order of average heights and weights. Region 1 (Highlands) with few exceptions, leads for both boys and girls in respect of height and weight at 5,9, and 13 years, Region 4 (Southern Counties), another predominantly rural region, coming a close second. The amount by which the averages for Region 1 (Highlands) exceed the next highest averages is significant in nearly all instances (apart from those for Region 4). Similarly, the average heights and weights of children attending education authority schools in Region 6 (Glasgow) are significantly less than the corresponding figures for Region 3 (Edinburgh, Aberdeen, and Dundee), which has the next lowest averages.

(g) Comparison of Mean Heights and Weights of Children aged 16 years attending Scottish Education Authority Secondary Schools in Individual Regions with those for Scotland as a Whole, 1951-52 and 1952-53.-The total numbers of 16-year-old boys measured at systematic medical examinations in Scotland in sessions 1951-52 and 1952-53 were 2,697 and 2,902, the corresponding totals for the girls being 2,527 and 2,687. In Appendix Table E, the actual average measurements have been adjusted to the uniform age of $16_{\frac{7}{12}}^{7}$ years, the factors employed being those based on the measurements of 16-year-old pupils attending Edinburgh education authority secondary schools during the three sessions 1951-52 to 1953-54.

Appendix Table E shows that the average measurements of the 16-year-olds in Scotland were:

$$
\begin{aligned}
& \text { Boys: } \\
& 67 \cdot 59 \text { in. and } 135 \cdot 67 \mathrm{lb} .(1951-52) ; \\
& 67 \cdot 70 \text { in. and } 134 \cdot 91 \mathrm{lb} \text {. }(1952-53) \text {. } \\
& \text { Girls: } \\
& 63 \cdot 66 \text { in. and } 123 \cdot 64 \mathrm{lb} .(1951-52) ; \\
& 63 \cdot 66 \mathrm{in} \text {. and } 123 \cdot 57 \mathrm{lb} \text {. (1952-53). }
\end{aligned}
$$

First, it should be observed that, although the average height of the 16-year-old boys for 1952-53 is above the corresponding average measurement for 1951-52, the difference is not significant; the average height of the 16-year-old girls is identical for the two sessions. The difference between the average weights for the two sessions, for both boys and girls, is not significant.

As has already been mentioned, the 16-year-olds do not form a representative cross-section of the children of that age group in any of the regions, as about two-thirds of the fathers are in Social Classes I or II or in the more highly-skilled occupations of Social Class III. From region to region they form a not dissimilar socio-economic group, and it is to be expected that the average heights and weights will be similar. In fact, relatively few of the average measurements for the individual regions are significantly above or below the corresponding all-Scotland averages; there are only two significant differences common to both sessions:

The average weight of the boys of Region 1 (Highlands) is significantly above that for Scotland as a whole $(t=2 \cdot 7$ and $3 \cdot 0)$, and the average height of the girls of Region 3 (Edinburgh, Aberdeen, and Dundee) is significantly below that for Scotland as a whole $(t=2 \cdot 5$ and $2 \cdot 1)$. 
It is interesting to note a particular conclusion reached by Martin (1949): "It appears that Scotsmen to-day do not differ in stature from their fathers or their great-grandfathers." Morant (1950) showed that the average height of present-day recruits into the Royal Air Force does not increase after about 20 years, whereas that of recruits into the army in 1913 increased until 24 years of age. Clements and Pickett (1952), analysing a sample of medical records of the Ministry of Labour and National Service for the first quarter of 1941 for 3,700 Scotsmen $(1,800$ of them between 18 and 24 years of age), concluded that "Scotsmen of all social classes reach adult stature by the 19th year." These and many other investigators think that the faster growth among schoolchildren of the past 20 years and the earlier attainment of maximum mature height implies no increase in the final stature of young adults.

There have been relatively few attempts, especially in recent years, to compare directly the heights of a group of parents with three of their offspring, but Durnin and Weir (1952), in a comparison of the heights of groups of men and women students of the University of Glasgow with those of their parents, showed the men students to be $1.8 \mathrm{in}$. taller on an average than their fathers, and the women students to be 1.7 in. taller than their mothers. These results led to the conclusion that it was unlikely that these differences were wholly due to shrinkage of the parents, and that a real secular increase in height was at least a contributory factor. Moreoever, evidence recently furnished by Acheson and Hewitt (1954) in respect of nearly 600 pre-school children in Oxford lends support to the hypothesis of an increasing fulfilment of "growth potential", and thus of a net increase in the height of the adult population.

It is doubtful, however, whether a firm conclusion about this particular problem is possible, and the general question of the extent to which differences in stature (and body-weight) are determined by genetic or environmental factors is likely to remain controversial. It may well be, however, as Berry and Cowin (1954) presume, that "the answers to all those problems will ultimately be writ clear in the stature of future generations", partly as a result of the long-term research studies that are now afoot.

(4) Average Heights and Weights of the SchoolCHILDREN OF FOUR HIGHLY INDUSTRIAL LARGE BURGHS COMPARED WITH THOSE OF THE CHILDREN OF Four Less Industrial LARge Burghs, at 5, 9, 13, AND 16 Years, 1952-53.

In a sense this comparison is simply a variant of the preceding regional analysis. Just as the average heights and weights for children of the highly industrial city of Glasgow (Region 6) are significantly lower than the corresponding averages for the children of the less industrial Region 3 formed by the cities of Edinburgh, Aberdeen, and Dundee, so it is to be expected that the averages for the children of a group of industrial large burghs would be lower-possibly significantly so-than those for the children of a group of much less industrial large burghs.

To determine whether this was indeed so, the large burghs of Dumbarton, Falkirk, Kilmarnock, and Kirkcaldy were chosen for the highly industrial group, and the large burghs of Perth, Stirling, Ayr, and Dunfermline (three of these situated close to their "industrial" counterparts) for the less industrial group. The total number of children of the four age groups concerned who were measured during 1952-53 varied within each of the two groups of burghs from 1,300 to 2,500 .

The particulars in Table $X$ (overleaf) are drawn from Appendix Table F, the average heights and weights of both boys and girls having been adjusted to the uniform ages of $5 \frac{\frac{1}{12}}{12}, 9_{\frac{6}{12}}, 13_{\frac{6}{12}}$, and $16_{\frac{7}{12}}^{7}$ years, by use of the factors based on the recent measurements of children attending the Edinburgh education authority schools.

Analysis shows that at 5 and 9 years, for boys and girls alike, the average. heights and weights of the children of the four highly industrial large burghs are significantly lower than the corresponding averages for the four less industrial large burghs. At 13 years the averages for the children of the highly industrial group are all lower than those for the children of the less industrial group, but in one instance only, the average height for girls, is the difference of statistical significance $(t=7 \cdot 9)$; at 16 years the averages for the children of the highly industrial group are lower, all the differences being significant except that relating to the average weight for girls.

It has to be noted, however, that, by the age of 13 years, in most of the eight burghs concerned, the "native-born" school population has been augmented to a variable extent by "migrants" from the county landward areas who are pursuing studies at secondary schools, and precise information is not available as to the number of those "migrants"; at 16 years of age also, there is continuance of this particular difficulty and, moreover, the total numbers are small.

The general trend, however, is interesting, and the findings in respect of the 5 and 9-year-olds, who are 
TABLE X

EIGHT LARGE BURGHS, FOUR INDUSTRIAL AND FOUR NON-INDUSTRIAL MEAN HEIGHTS AND WEIGHTS OF SCHOOL CHILDREN AT $54 / 12,9 \%: 2,13 \%, 12$, and $16 \% 12$ YEARS SESSION 1952-53

\begin{tabular}{|c|c|c|c|c|c|c|c|c|c|}
\hline \multicolumn{2}{|c|}{ Age (yrs) } & \multicolumn{2}{|c|}{5} & \multicolumn{2}{|c|}{9} & \multicolumn{2}{|c|}{13} & \multicolumn{2}{|c|}{16} \\
\hline Measu & Irement $\ldots \quad \ldots$ & $\begin{array}{l}\text { Height } \\
\text { (in.) }\end{array}$ & $\begin{array}{l}\text { Weight } \\
\text { (lb.) }\end{array}$ & $\begin{array}{l}\text { Height } \\
\text { (in.) }\end{array}$ & $\begin{array}{l}\text { Weight } \\
\text { (lb.) }\end{array}$ & $\begin{array}{l}\text { Height } \\
\text { (in.) }\end{array}$ & $\begin{array}{l}\text { Weight } \\
\text { (lb.) }\end{array}$ & $\begin{array}{l}\text { Height } \\
\text { (in.) }\end{array}$ & $\begin{array}{l}\text { Weight } \\
\text { (lb.) }\end{array}$ \\
\hline \multirow{3}{*}{ Boys } & \multirow{2}{*}{$\begin{array}{l}\text { Industrial Large } \\
\text { Burghs .. } \\
\text { "Non-industrial" } \\
\text { Large Burghs . }\end{array}$} & $43 \cdot 45$ & $42 \cdot 55$ & $51 \cdot 53$ & $63 \cdot 34$ & $59 \cdot 59$ & $93 \cdot 95$ & $67 \cdot 34$ & $130 \cdot 91$ \\
\hline & & $43 \cdot 93$ & $44 \cdot 00$ & $53 \cdot 17$ & $65 \cdot 06$ & $59 \cdot 66$ & $94 \cdot 45$ & $68 \cdot 07$ & $136 \cdot 04$ \\
\hline & Difference $\quad \stackrel{ }{ }=$ & $\begin{array}{l}0 \cdot 48 \\
7 \cdot 1\end{array}$ & $\begin{array}{l}1 \cdot 45 \\
8 \cdot 8\end{array}$ & $\begin{array}{l}1 \cdot 74 \\
16 \cdot 0\end{array}$ & $\begin{array}{l}1 \cdot 72 \\
4 \cdot 6\end{array}$ & $\begin{array}{l}0.07 \\
0.5\end{array}$ & $\begin{array}{l}0.50 \\
0.7\end{array}$ & $\begin{array}{l}0 \cdot 73 \\
2 \cdot 5\end{array}$ & $\begin{array}{l}5 \cdot 13 \\
8 \cdot 8\end{array}$ \\
\hline \multirow{3}{*}{ Girls } & \multirow{2}{*}{$\begin{array}{l}\text { Industrial Large } \\
\text { Burghs . } \\
\text { "Non-Industrial" } \\
\text { Large Burghs . . }\end{array}$} & $42 \cdot 37$ & $40 \cdot 81$ & $51 \cdot 19$ & $60 \cdot 84$ & $59 \cdot 44$ & $96 \cdot 81$ & $63 \cdot 69$ & $123 \cdot 53$ \\
\hline & & $42 \cdot 93$ & $41 \cdot 55$ & $52 \cdot 65$ & $62 \cdot 73$ & $60 \cdot 31$ & $97 \cdot 72$ & $64 \cdot 44$ & $124 \cdot 06$ \\
\hline & Difference $\quad t \stackrel{\circ}{=}$ & $\begin{array}{l}0 \cdot 56 \\
8 \cdot 2\end{array}$ & $\begin{array}{l}0 \cdot 74 \\
4 \cdot 4\end{array}$ & $\begin{array}{l}1 \cdot 46 \\
12 \cdot 0\end{array}$ & $\begin{array}{l}1 \cdot 89 \\
4 \cdot 7\end{array}$ & $\begin{array}{l}0 \cdot 87 \\
7 \cdot 9\end{array}$ & $\begin{array}{l}0.91 \\
1.4\end{array}$ & $\begin{array}{l}0 \cdot 75 \\
3 \cdot 1\end{array}$ & $\begin{array}{l}1 \cdot 07 \\
1 \cdot 8\end{array}$ \\
\hline
\end{tabular}

nearly all "native-born", are of importance for the present purpose, being in line with some of the main findings of the regional analysis on a geographical industrial grouping.

\section{SUMmary}

(1) It is claimed that, although the increase in average heights and weights of children attending education authority schools in Edinburgh and Glasgow over the past 40 years may not be typical of Scotland as a whole, it illustrates the position in most of the populous industrial centres.

It is shown that the average measurements of children aged 5, 9, and 13 years in Edinburgh and Glasgow in session 1953-54 are all significantly greater than the corresponding averages for 1913-14. A few of these averages had already increased significantly by 1931-32, but the chief increases have occurred in steady annual increments during the past 20 years.

In 1913-14 the average measurements for the Edinburgh children at 5, 9, and 13 years were all above the corresponding averages for the Glasgow children. As time passed, most of these "gaps" were appreciably closed, but even so the present-day differences in favour of the Edinburgh children are statistically significant, with only one exception.

The proportionate increases in the average measurements of Glasgow boys and girls between 5 and 9 years, 9 and 13 years, and 5 and 13 years are closely similar for those born in 1925 and in subsequent years up to and including 1940.
(2) Edinburgh, Glasgow, Dundee, and Ayrshire together fairly represent the school population of the populous central industrial belt of Scotland. A study of the average measurements of schoolchildren aged $5,9,13$, and 16 years for the 6-year period, 1948-49 to 1953-54, shows that by 1953-54 all the averages had risen, for boys and girls alike, the difference being significant in each instance. A comparison between 1952-53 and 1953-54 shows differences favouring the latter session in practically all cases, most of these differences being statistically significant.

Together, these results show a continuance of the upward trend in the average heights and weights of schoolchildren that has characterized the past two decades.

(3) The general situation throughout Scotland in regard to the weighing and measuring of schoolchildren at systematic medical examination is reviewed. In the subsequent analysis, the country is divided on a geographical-industrial basis into six regions:

Region 1, Highlands;

Region 2, Eastern Counties;

Region 3, Edinburgh, Aberdeen, and Dundee;

Region 4, Southern Counties;

Region 5, Western and Central Industrial Region (excluding Glasgow);

Region 6, Glasgow.

The average heights and weights of children aged $5,9,13$, and 16 years attending education authority schools in sessions 1951-52 and 1952-53 are adjusted to the uniform ages of $5 \frac{4}{12}, 9 \frac{6}{12}, 13 \frac{6}{12}$, and $6 \frac{7}{12}$ years. 
In the analysis a distinction is made between children aged 5,9, and 13 years on the one hand and those aged 16 years on the other, as the 16-year-old secondary school pupils do not form a representative cross-section of the members of this age group in the community.

The all-Scotland averages for boys in session 1952-53 are:

$43 \cdot 00$ in. and $43 \cdot 12 \mathrm{lb}$. at 5 years.

$51 \cdot 93 \mathrm{in}$. and $64 \cdot 27 \mathrm{lb}$. at 9 years.

$59 \cdot 52$ in. and $93.52 \mathrm{lb}$. at 13 years.

The corresponding all-Scotland averages for girls in session 1952-53 are:

$42.61 \mathrm{in}$. and $41.50 \mathrm{lb}$. at 5 years.

$51.54 \mathrm{in}$. and $62.04 \mathrm{lb}$. at 9 years.

59.99 in. and $97.53 \mathrm{lb}$. at 13 years.

These average measurements, in comparison with their counterparts for 1951-52, provide additional evidence of a continuance of the upward trend in the average heights and weights of both boys and girls.

Arrangements of the regions in descending order of measurements brings out the following points:

(i) Region 1 (Highlands) and Region 4 (Southern) Counties)-commonly in that order-almost invariably have the highest average values for both height and weight for both boys and girls.

(ii) Region 6 (Glasgow) provides the lowest average heights, with one exception, and the lowest average weights, with Region 3 (Edinburgh, Aberdeen, and Dundee) most commonly providing the next lowest average measurements.

(iii) Region 2 (Eastern Counties) and Region 5 (Western and Central Industrial Region, excluding Glasgow) occupy intermediate positions, with the former, on balance, the more favourably situated.

(iv) For each of the two sessions, for both boys and girls, the order of average weights in a particular age group approximates closely, with few exceptions, to the order of the average heights.

(v) At 5, 9, and 13 years, the average measurements of children in the predominantly rural regions (1 and 4) are above the corresponding all-Scotland averages, the differences being almost invariably of statistical significance. In contrast, for each age group, the average measurements of children in the predominantly industrial regions (6 and 3 ) are below the corresponding all-Scotland averages, the differences being almost invariably significant. (vi) The arrangement of the six regions in descending order of average heights and weights of children at 5, 9, and 13 years gives results that agree closely with the findings of Martin (1949) in an inquiry into the average heights and weights of young adult Scotsmen examined under the Military Training Act, 1939.

(viii) In the session 1952-53 the average measurements of the 2,902 16-year-old boys in attendance at education authority secondary schools throughout Scotland (measurements adjusted to the uniform age of $16_{\frac{1}{2}}^{\frac{7}{2}}$ years) were $67.70 \mathrm{in}$. and $134.91 \mathrm{lb}$., and those of the 2,687 16-year-old girls were 63.66 in. and $123.57 \mathrm{lb}$. From region to region, so far as the occupations of the fathers are concerned, these 16-year-old pupils may be said to form a not dissimilar socio-economic group, of a level somewhat above that of the 16-year-olds in the community as a whole; in keeping with this, relatively few of the average measurements for the individual regions are significantly above or below the corresponding all-Scotland average.

(4) In addition to the regional analysis, the average measurements at $5,9,13$, and 16 years of the schoolchildren of four highly industrial large burghs are compared with those of four less industrial large burghs. For both boys and girls, the average heights and weights in each age group in the highly industrial group of large burghs are below the corresponding averages for the less industrial group, most of the differences being statistically significant.

It is a pleasure to record my thanks to the medical officers of health and school medical officers throughout Scotland for their collaboration in checking the accuracy of the returns of heights and weights of schoolchildren for sessions 1951-52 and 1952-53; in particular, thanks are due to the medical, nursing, and clerical staffs of the school health departments in Edinburgh, Glasgow, Dundee, and Ayrshire for the careful recording, over the years, of the results of the systematic medical examinations.

Indebtedness is expressed to Dr. John Riddell, medical officer of health for the Counties of Midlothian and Peebles, and Mr. James Maxwell, principal lecturer in psychology at Moray House Training. College, Edinburgh, for their most helpful advice and criticism.

I acknowledge with gratitude the encouragement of Dr. H. Kenneth Cowan, chief medical officer, Department of Health for Scotland, and Dr. W. B. Inglis, O.B.E., director of studies, Moray House Training College.

\section{REFERENCES}

Acheson, R. M., and Hewitt, D. (1954). British Journal of Preventive and Social Medicine, 8, 59.

Berry, W. T. C., and Cowin, P. J. (1954). Brit. med. J., 1, 847. 
Clements, E. M. B., and Pickett, K. G. (1952). British Journal of Preventive and Social Medicine, 6, 245.

Daley, A. (1950). "Report on the Heights and Weights of School Pupils in the County of London in 1949". Staples Press, London. Durnin, J. V. G. A., and Weir, J. B. de V. (1952). Brit. med. J., $1,1006$.

General Register Office (1951). "Classification of Occupations, 1950". H.M.S.O., London.

Martin, W. J. (1949). "The Physique of Young Adult Males",

Medical Research Council Mem. Mo. 20. H.M.S.O., London.
Ministry of Education (1954). "Early Leaving". A Report of the Central Advisory Council for Education (England). H.M.S.O. London.

Morant, G. M. (1950). Proc. roy. Soc. B., 137, 443.

Scottish Council for Research in Education (1953). "Social Implications of the 1947 Scottish Mental Survey". Publications of the Scottish Council for Research in Education, XXXV. University of London Press, London.

\section{APPENDIX}

TABLE A

CITIES OF EDINBURGH AND GLASGOW EDUCATION AUTHORITY SCHOOLS

SESSIONS 1913-14 TO 1953-54

AVERAGE HEIGHTS AND WEIGHTS OF CHILDREN OF 5, 9, AND 13 YEARS OF AGE EXAMINED IN SCHOOL DURING SYSTEMATIC MEDICAL INSPECTION*

\begin{tabular}{|c|c|c|c|c|c|c|c|c|}
\hline \multirow{2}{*}{$\frac{\text { Age (yrs) }}{\text { City }}$} & \multirow{2}{*}{$\cdots$} & \multirow{2}{*}{$\begin{array}{l}\cdots \\
\begin{array}{l}\text { School } \\
\text { Session }\end{array}\end{array}$} & \multicolumn{2}{|c|}{5} & \multicolumn{2}{|c|}{9} & \multicolumn{2}{|c|}{13} \\
\hline & & & $\begin{array}{l}\text { Height } \\
\quad \text { (in.) }\end{array}$ & $\begin{array}{l}\text { Weight } \\
\text { (lb.) }\end{array}$ & $\begin{array}{l}\text { Height } \\
\text { (in.) }\end{array}$ & $\begin{array}{l}\text { Weight } \\
\text { (lb.) }\end{array}$ & $\begin{array}{l}\text { Height } \\
\text { (in.) }\end{array}$ & $\begin{array}{c}\text { Weight } \\
\text { (lb.) }\end{array}$ \\
\hline \multirow{2}{*}{ Edinburgh } & Boys & $\begin{array}{l}1913-14 \\
1920-21 \\
1926-27 \\
1931-32 \\
1937-38 \\
1949-50 \\
1953-54\end{array}$ & $\begin{array}{l}41 \cdot 5 \\
41 \cdot 3 \\
41 \cdot 6 \\
42 \cdot 3 \\
42 \cdot 48 \\
42 \cdot 61 \\
42 \cdot 79\end{array}$ & $\begin{array}{l}40 \cdot 6 \\
40 \cdot 7 \\
42 \cdot 2 \\
40 \cdot 4 \\
41 \cdot 84 \\
42 \cdot 78 \\
42 \cdot 67\end{array}$ & $\begin{array}{c}48 \cdot 8 \\
49 \cdot 5 \\
48 \cdot 4 \\
48 \cdot 6 \\
\text { not } \\
51 \cdot 59 \\
51 \cdot 72\end{array}$ & $\begin{array}{l}56 \cdot 6 \\
58 \cdot 0 \\
55 \cdot 8 \\
54 \cdot 5 \\
\text { ble } \\
\quad 64 \cdot 04 \\
64 \cdot 05\end{array}$ & $\begin{array}{r}56 \cdot 0 \\
55 \cdot 9 \\
56 \cdot 8 \\
58 \cdot 2 \\
\text { no } \\
58 \cdot 96 \\
59 \cdot 57\end{array}$ & $\begin{array}{l}78 \cdot 9 \\
76 \cdot 4 \\
85 \cdot 7 \\
88 \cdot 4 \\
\text { ble } \\
91 \cdot 37 \\
93 \cdot 27\end{array}$ \\
\hline & Girls & $\begin{array}{l}1913-14 \\
1920-21 \\
1926-27 \\
1931-32 \\
1937-38 \\
1949-50 \\
1953-54\end{array}$ & $\begin{array}{l}41 \cdot 2 \\
40 \cdot 0 \\
40 \cdot 5 \\
41 \cdot 3 \\
42 \cdot 12 \\
42 \cdot 14 \\
42 \cdot 24\end{array}$ & $\begin{array}{l}39 \cdot 6 \\
39 \cdot 1 \\
39 \cdot 3 \\
39 \cdot 0 \\
40 \cdot 34 \\
41 \cdot 21 \\
40 \cdot 91\end{array}$ & $\begin{array}{c}48 \cdot 7 \\
49 \cdot 2 \\
48 \cdot 9 \\
48 \cdot 7 \\
\text { not } \\
51 \cdot 08 \\
51 \cdot 00\end{array}$ & $\begin{array}{c}55 \cdot 7 \\
55 \cdot 8 \\
53 \cdot 5 \\
53 \cdot 2 \\
\text { ble } \\
\quad 62 \cdot 26 \\
62 \cdot 89\end{array}$ & $\begin{array}{c}59 \cdot 0 \\
56 \cdot 9 \\
55 \cdot 6 \\
59 \cdot 6 \\
\text { no } \\
59 \cdot 74 \\
59 \cdot 85\end{array}$ & $\begin{array}{c}84 \cdot 3 \\
79 \cdot 1 \\
82 \cdot 7 \\
92 \cdot 5 \\
\text { ble } \\
96 \cdot 59 \\
96 \cdot 98\end{array}$ \\
\hline \multirow{2}{*}{ Glasgow } & Boys & $\begin{array}{l}1913-14 \\
1920-21 \\
1926-27 \\
1931-32 \\
1937-38 \\
1949-50 \\
1953-54\end{array}$ & $\begin{array}{l}40 \cdot 5 \\
40 \cdot 2 \\
40 \cdot 9 \\
41 \cdot 1 \\
41 \cdot 65 \\
42 \cdot 47 \\
42 \cdot 43\end{array}$ & $\begin{array}{l}37 \cdot 7 \\
39 \cdot 5 \\
39 \cdot 3 \\
39 \cdot 4 \\
40 \cdot 52 \\
42 \cdot 31 \\
42 \cdot 05\end{array}$ & $\begin{array}{l}47 \cdot 4 \\
49 \cdot 1 \\
49 \cdot 5 \\
49 \cdot 3 \\
50 \cdot 23 \\
51 \cdot 08 \\
51 \cdot 40\end{array}$ & $\begin{array}{l}54 \cdot 8 \\
54 \cdot 4 \\
56 \cdot 4 \\
57 \cdot 0 \\
59 \cdot 45 \\
61 \cdot 84 \\
63 \cdot 16\end{array}$ & $\begin{array}{l}55 \cdot 1 \\
54 \cdot 7 \\
56 \cdot 1 \\
56 \cdot 3 \\
57 \cdot 33 \\
58 \cdot 60 \\
59 \cdot 01\end{array}$ & $\begin{array}{l}76 \cdot 4 \\
74 \cdot 8 \\
78 \cdot 8 \\
79 \cdot 8 \\
83 \cdot 45 \\
88 \cdot 43 \\
90 \cdot 93\end{array}$ \\
\hline & Girls & $\begin{array}{l}1913-14 \\
1920-21 \\
1926-27 \\
1931-32 \\
1937-38 \\
1949-50 \\
1953-54\end{array}$ & $\begin{array}{l}40 \cdot 4 \\
39 \cdot 8 \\
40 \cdot 7 \\
40 \cdot 7 \\
41 \cdot 34 \\
42 \cdot 00 \\
42 \cdot 04\end{array}$ & $\begin{array}{l}37 \cdot 0 \\
38 \cdot 1 \\
38 \cdot 1 \\
37 \cdot 8 \\
39 \cdot 01 \\
40 \cdot 46 \\
40 \cdot 69\end{array}$ & $\begin{array}{l}48 \cdot 3 \\
48 \cdot 3 \\
48 \cdot 8 \\
49 \cdot 1 \\
49 \cdot 98 \\
50 \cdot 54 \\
50 \cdot 83\end{array}$ & $\begin{array}{l}54 \cdot 1 \\
53 \cdot 5 \\
54 \cdot 3 \\
55 \cdot 0 \\
57 \cdot 59 \\
59 \cdot 64 \\
61 \cdot 08\end{array}$ & $\begin{array}{l}56 \cdot 3 \\
56 \cdot 5 \\
56 \cdot 5 \\
57 \cdot 3 \\
58 \cdot 47 \\
59 \cdot 22 \\
59 \cdot 48\end{array}$ & $\begin{array}{l}79 \cdot 0 \\
78 \cdot 5 \\
82 \cdot 1 \\
83 \cdot 7 \\
88 \cdot 93 \\
93 \cdot 16 \\
95 \cdot 41\end{array}$ \\
\hline
\end{tabular}

* Measurements adjusted in 1937-38, 1949-50, and 1953-54 to the uniform ages of $54 / 12,95 / 12$, and $13 \% / 12$ years. In earlier sessions the average ages at time of measurement approximated closely to these.

TABLE B

CITIES OF EDINBURGH, GLASGOW, AND DUNDEE, AND COUNTY OF AYR EDUCATION AUTHORITY SCHOOLS-SESSIONS 1948-49 TO 1953-54

NUMBERS AND THE AVERAGE HEIGHTS AND WEIGHTS OF CHILDREN OF 5, 9, 13, AND 16 YEARS OF AGE EXAMINED IN SCHOOL DURING SYSTEMATIC MEDICAL INSPECTION

ADJUSTED AVERAGE MEASUREMENTS (UNIFORM AGES OF $54 / 12,96 / 12,136 / 12$, AND $16^{7} / 12$ YEARS RESPECTIVELY)

\begin{tabular}{|c|c|c|c|c|c|c|c|c|c|c|c|c|c|}
\hline \multirow{2}{*}{$\begin{array}{c}\text { Age Group } \\
\text { Sex }\end{array}$} & \multirow{2}{*}{$\begin{array}{l}\cdots \\
\begin{array}{c}\text { School } \\
\text { Session }\end{array}\end{array}$} & \multicolumn{3}{|c|}{$\begin{array}{c}\text { Entrant Infants } \\
(5 \% \text { yrs })\end{array}$} & \multicolumn{3}{|c|}{$\begin{array}{c}\text { Second Age Group } \\
(9 \% 12 \text { yrs })\end{array}$} & \multicolumn{3}{|c|}{$\begin{array}{c}\text { Third Age Group } \\
\left(13^{6} / 12 \text { yrs }\right)\end{array}$} & \multicolumn{3}{|c|}{$\begin{array}{c}\text { Secondary Schools } \\
\text { Age Group }\left(16^{\%} / 12 \text { yrs }\right)\end{array}$} \\
\hline & & $\begin{array}{c}\text { No. } \\
\text { Examined }\end{array}$ & $\begin{array}{c}\text { Height } \\
\text { (in.) }\end{array}$ & $\begin{array}{l}\text { Weight } \\
\text { (lb.) }\end{array}$ & $\begin{array}{l}\text { No. } \\
\text { Examined }\end{array}$ & $\begin{array}{l}\text { Height } \\
\text { (in.) }\end{array}$ & $\begin{array}{c}\text { Weight } \\
\text { (lb.) }\end{array}$ & $\begin{array}{l}\text { No. } \\
\text { Examined }\end{array}$ & $\begin{array}{l}\text { Height } \\
\text { (in.) }\end{array}$ & $\begin{array}{l}\text { Weight } \\
\text { (lb.) }\end{array}$ & $\begin{array}{l}\text { No. } \\
\text { Examined }\end{array}$ & $\begin{array}{l}\text { Height } \\
\text { (in.) }\end{array}$ & $\begin{array}{l}\text { Weight } \\
\text { (lb.) }\end{array}$ \\
\hline Boys & $\begin{array}{l}1948-49 \\
1949-50 \\
1950-51 \\
1951-52 \\
1952-53 \\
1953-54\end{array}$ & $\begin{array}{l}14,903 \\
14,837 \\
14,154 \\
17,241 \\
17,652 \\
16,903\end{array}$ & $\begin{array}{l}42 \cdot 65 \\
42 \cdot 63 \\
42 \cdot 67 \\
42 \cdot 66 \\
42 \cdot 65 \\
42 \cdot 73\end{array}$ & $\begin{array}{l}42 \cdot 36 \\
42 \cdot 63 \\
42 \cdot 60 \\
42 \cdot 58 \\
42 \cdot 61 \\
42 \cdot 54\end{array}$ & $\begin{array}{l}12,211 \\
11,949 \\
11,951 \\
11,709 \\
12,289 \\
13,487\end{array}$ & $\begin{array}{l}51 \cdot 69 \\
51 \cdot 66 \\
51 \cdot 53 \\
51 \cdot 79 \\
51 \cdot 55 \\
51 \cdot 82\end{array}$ & $\begin{array}{l}63 \cdot 49 \\
63 \cdot 47 \\
62 \cdot 92 \\
63 \cdot 35 \\
63 \cdot 29 \\
64 \cdot 09\end{array}$ & $\begin{array}{l}11,213 \\
12,019 \\
12 \cdot 038 \\
12,530 \\
11,937 \\
12,227\end{array}$ & $\begin{array}{l}59 \cdot 00 \\
59 \cdot 05 \\
59 \cdot 24 \\
59 \cdot 36 \\
59 \cdot 40 \\
59 \cdot 56\end{array}$ & $\begin{array}{l}90 \cdot 01 \\
91 \cdot 02 \\
91 \cdot 95 \\
91 \cdot 79 \\
92 \cdot 68 \\
93 \cdot 37\end{array}$ & $\begin{array}{r}1,010 \\
1,010 \\
993 \\
1,022 \\
1,101 \\
1,314\end{array}$ & $\begin{array}{l}66 \cdot 86 \\
67 \cdot 34 \\
67 \cdot 53 \\
67 \cdot 44 \\
67 \cdot 55 \\
67 \cdot 64\end{array}$ & $\begin{array}{l}130 \cdot 60 \\
132 \cdot 71 \\
133 \cdot 11 \\
133 \cdot 86 \\
132 \cdot 39 \\
134 \cdot 48\end{array}$ \\
\hline Girls & $\begin{array}{l}1948-49 \\
1949-50 \\
1950-51 \\
1951-52 \\
1952-53 \\
1953-54\end{array}$ & $\begin{array}{l}14,177 \\
14,143 \\
13,409 \\
16,774 \\
17,197 \\
15,960\end{array}$ & $\begin{array}{l}42 \cdot 19 \\
42 \cdot 19 \\
42 \cdot 29 \\
42 \cdot 32 \\
42 \cdot 34 \\
42 \cdot 48\end{array}$ & $\begin{array}{l}40 \cdot 69 \\
40 \cdot 97 \\
41 \cdot 05 \\
40 \cdot 91 \\
40 \cdot 96 \\
41 \cdot 10\end{array}$ & $\begin{array}{l}11,423 \\
11,778 \\
11,575 \\
11,779 \\
11,487 \\
13,170\end{array}$ & $\begin{array}{l}51 \cdot 05 \\
51 \cdot 08 \\
51 \cdot 13 \\
51 \cdot 14 \\
51 \cdot 30 \\
51 \cdot 34\end{array}$ & $\begin{array}{l}60 \cdot 72 \\
61 \cdot 32 \\
61 \cdot 29 \\
61 \cdot 34 \\
61 \cdot 60 \\
62 \cdot 45\end{array}$ & $\begin{array}{l}11,289 \\
12,226 \\
12,198 \\
12,594 \\
11,578 \\
12,604\end{array}$ & $\begin{array}{l}59 \cdot 35 \\
59 \cdot 59 \\
59 \cdot 62 \\
59 \cdot 95 \\
59 \cdot 84 \\
59 \cdot 96\end{array}$ & $\begin{array}{l}94 \cdot 22 \\
92 \cdot 12 \\
95 \cdot 65 \\
97 \cdot 50 \\
96 \cdot 72 \\
97 \cdot 37\end{array}$ & $\begin{array}{c}782 \\
707 \\
801 \\
907 \\
925 \\
1,150\end{array}$ & $\begin{array}{l}63 \cdot 49 \\
63 \cdot 54 \\
63 \cdot 36 \\
63 \cdot 67 \\
63 \cdot 64 \\
63 \cdot 63\end{array}$ & $\begin{array}{l}121 \cdot 24 \\
121 \cdot 68 \\
123 \cdot 21 \\
123 \cdot 63 \\
122 \cdot 70 \\
122 \cdot 81\end{array}$ \\
\hline
\end{tabular}


TABLE C

BOYS ATTENDING SCOTTISH EDUCATION AUTHORITY SCHOOLS-SESSIONS 1951-52 and 1952-53

NUMBERS AND AVERAGE HEIGHTS AND WEIGHTS OF BOYS OF 5, 9, AND 13 YEARS OF AGE EXAMINED IN SCHOOL DURING SYSTEMATIC MEDICAL INSPECTION

ADJUSTED AVERAGE MEASUREMENTS (UNIFORM AGES OF $5 \% 12,9 \% 12$, AND $13 \% 12$ YEARS RESPECTIVELY)

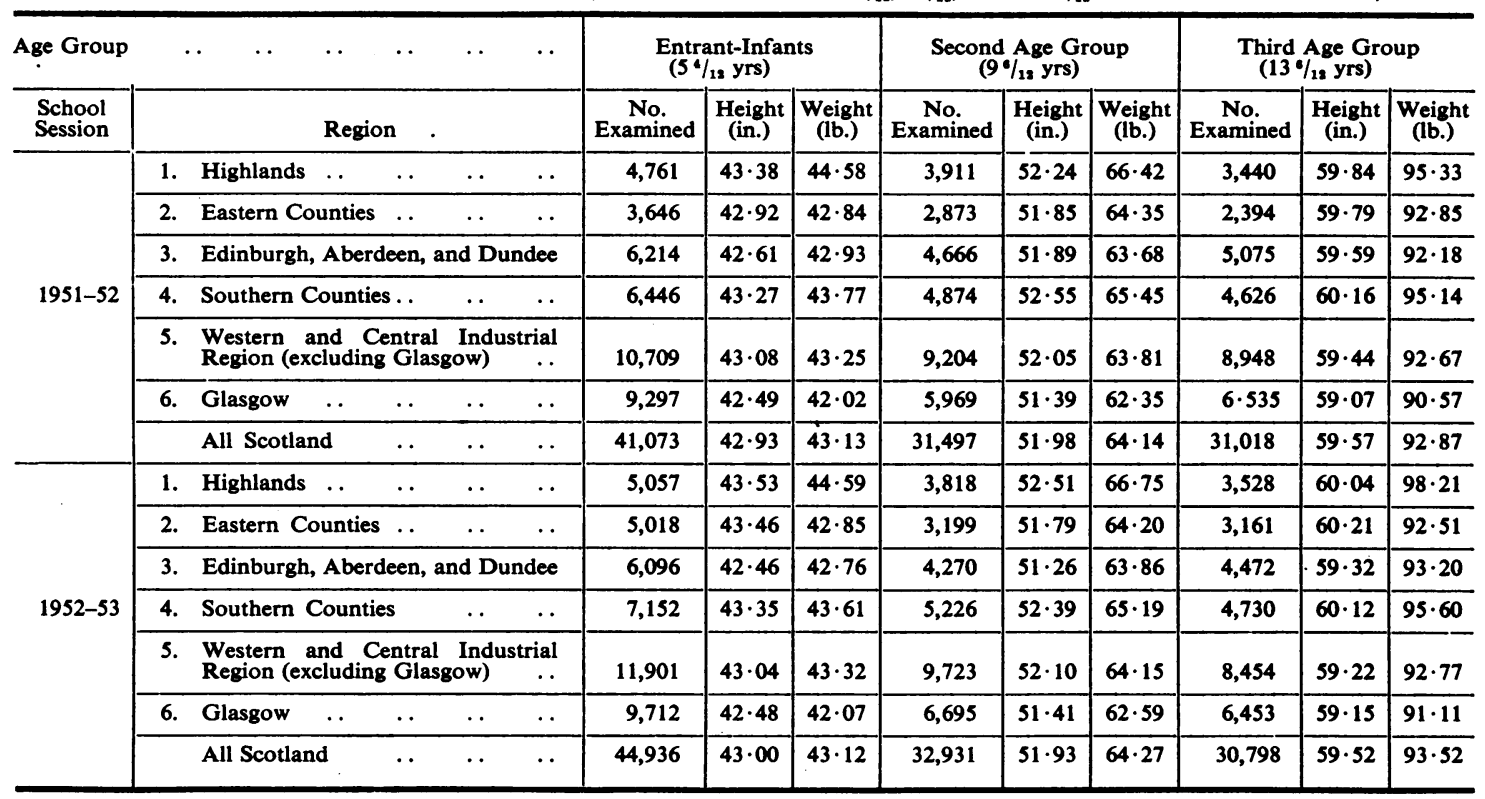

TABLE D

GIRLS ATTENDING SCOTTISH EDUCATION AUTHORITY SCHOOLS_SESSIONS 1951-52, 1952-53

NUMBERS AND THE AVERAGE HEIGHTS AND WEIGHTS OF GIRLS OF 5, 9, AND 13 YEARS OF AGE EXAMINED IN SCHOOL DURING SYSTEMATIC MEDICAL INSPECTION

ADJUSTED AVERAGE MEASUREMENTS (UNIFORM AGES OF $5 \%, 9 \%$ AND $13 \%$ YRS RESPECTIVELY)

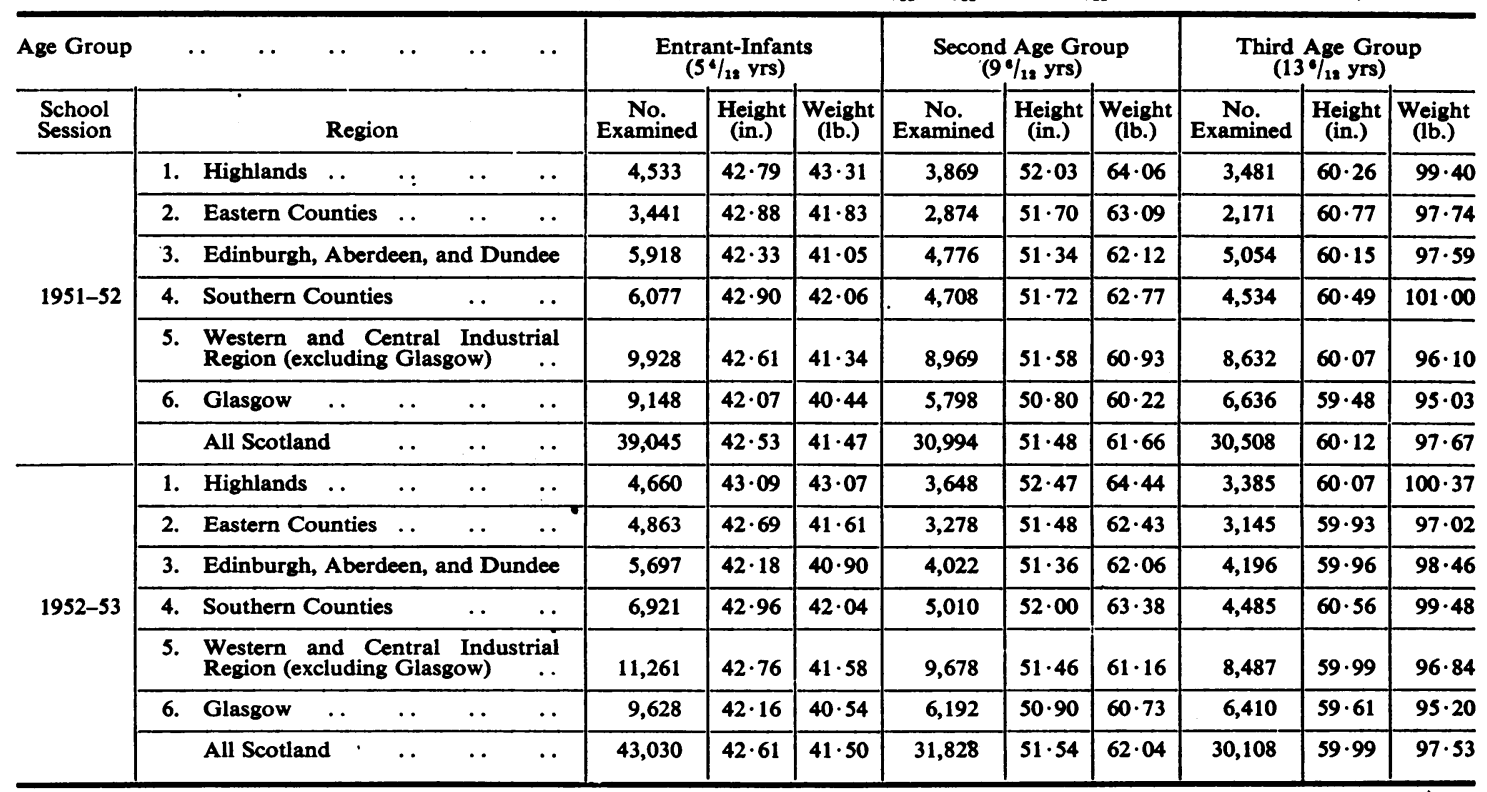


TABLE E

PUPILS ATTENDING SCOTTISH EDUCATION AUTHORITY SECONDARY SCHOOLS-SESSIONS 1951-52, 1952-53 NUMBERS AND THE AVERAGE HEIGHTS AND WEIGHTS OF PUPILS OF 16 YEARS OF AGE EXAMINED IN SCHOOL DURING SYSTEMATIC MEDICAL INSPECTION ADJUSTED AVERAGE MEASUREMENTS (UNIFORM AGE OF $16 \% 12$ YRS)

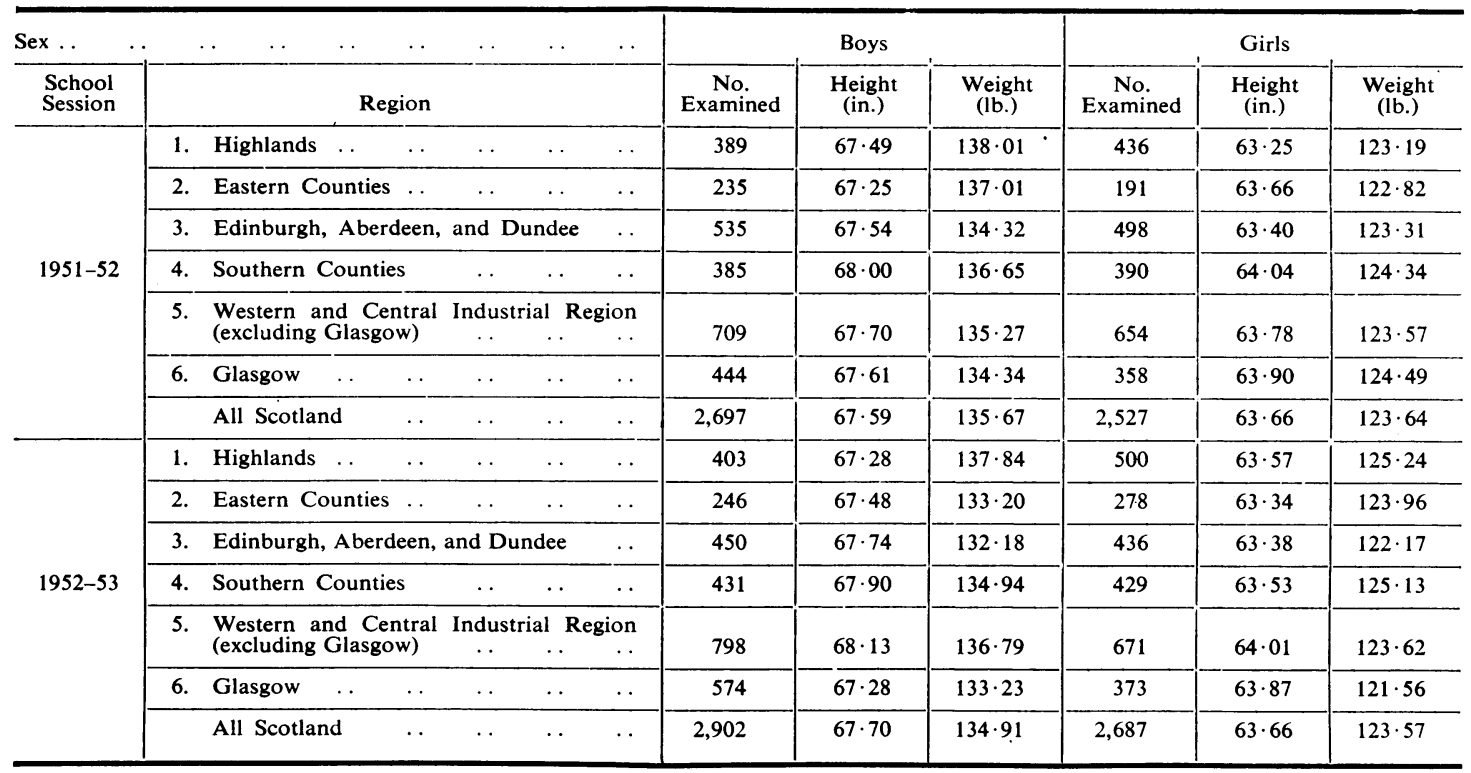

TABLE $F$

PUPILS ATTENDING EDUCATION AUTHORITY SCHOOLS-SESSION 1952-53, IN FOUR HIGHLY INDUSTRIAL AND FOUR LESS INDUSTRIAL LARGE BURGHS

NUMBERS AND THE AVERAGE HEIGHTS AND WEIGHTS OF PUPILS OF 5, 9, 13, AND 16 YEARS OF AGE EXAMINED IN SCHOOL DURING SYSTEMATIC MEDICAL INSPECTION

ADJUSTED AVERAGE MEASUREMENTS (UNIFORM AGES OF $54 / 12,96 / 12,13 \%, 12$, AND $16^{\%} / 12$ YRS RESPECTIVELY

\begin{tabular}{|c|c|c|c|c|c|c|c|c|c|c|c|c|c|}
\hline \multicolumn{2}{|c|}{ Age Group } & \multicolumn{3}{|c|}{$\begin{array}{l}\text { Entrant-Infants } \\
(54 / 12 \mathrm{yrs})\end{array}$} & \multicolumn{3}{|c|}{$\begin{array}{l}\text { Second Age Group } \\
(96 / 12 \text { yrs })\end{array}$} & \multicolumn{3}{|c|}{$\begin{array}{l}\text { Third Age Group } \\
\left(13^{6} / 12 \text { yrs }\right)\end{array}$} & \multicolumn{3}{|c|}{$\begin{array}{l}\text { Secondary Schools } \\
\text { Age Group }\left(16^{7} / 12 \text { yrs }\right)\end{array}$} \\
\hline Sex & Burghs & $\begin{array}{c}\text { No. } \\
\text { Examined }\end{array}$ & $\begin{array}{l}\text { Height } \\
\text { (in.) }\end{array}$ & $\begin{array}{c}\text { Weight } \\
\text { (lb.) }\end{array}$ & $\begin{array}{c}\text { No. } \\
\text { Examined }\end{array}$ & $\begin{array}{l}\text { Height } \\
\text { (in.) }\end{array}$ & $\begin{array}{l}\text { Weight } \\
\text { (lb.) }\end{array}$ & $\begin{array}{c}\text { No. } \\
\text { Examined }\end{array}$ & $\begin{array}{c}\text { Height } \\
\text { (in.) }\end{array}$ & $\begin{array}{l}\text { Weight } \\
\text { (lb.) }\end{array}$ & $\begin{array}{c}\text { No. } \\
\text { Examined }\end{array}$ & $\begin{array}{l}\text { Height } \\
\text { (in.) }\end{array}$ & $\begin{array}{l}\text { Weight } \\
\text { (lb.) }\end{array}$ \\
\hline \multirow{3}{*}{ Boys } & All eight burghs & 2,892 & $43 \cdot 69$ & $43 \cdot 27$ & 2,104 & $52 \cdot 41$ & $64 \cdot 22$ & 2,561 & $59 \cdot 56$ & $94 \cdot 20$ & 322 & $67 \cdot 74$ & $133 \cdot 74$ \\
\hline & $\begin{array}{l}\text { Four highly in- } \\
\text { dustrial burghs }\end{array}$ & 1,464 & $43 \cdot 45$ & $42 \cdot 55$ & 1,036 & $51 \cdot 53$ & $63 \cdot 34$ & 1,289 & $59 \cdot 59$ & $93 \cdot 95$ & 145 & $67 \cdot 34$ & $130 \cdot 91$ \\
\hline & Other four burghs & 1,428 & $43 \cdot 93$ & $44 \cdot 00$ & 1,068 & $53 \cdot 27$ & $65 \cdot 06$ & 1,272 & $59 \cdot 66$ & $94 \cdot 45$ & 177 & $68 \cdot 07$ & $136 \cdot 04$ \\
\hline \multirow{3}{*}{ Girls } & All eight burghs & 2,846 & $42 \cdot 65$ & $41 \cdot 19$ & 2,265 & $51 \cdot 93$ & $61 \cdot 78$ & 2,641 & 59.93 & $97 \cdot 25$ & 311 & $64 \cdot 10$ & $124 \cdot 02$ \\
\hline & $\begin{array}{l}\text { Four highly in- } \\
\text { dustrial burghs }\end{array}$ & 1,387 & $42 \cdot 37$ & $40 \cdot 81$ & 1,128 & $51 \cdot 19$ & $60 \cdot 84$ & 1,356 & $59 \cdot 44$ & $96 \cdot 81$ & 136 & $63 \cdot 69$ & $123 \cdot 53$ \\
\hline & Other four burghs & 1,459 & $42 \cdot 93$ & $41 \cdot 55$ & 1,137 & $52 \cdot 65$ & $62 \cdot 73$ & 1,285 & $60 \cdot 31$ & $97 \cdot 72$ & 175 & $64 \cdot 44$ & $124 \cdot 60$ \\
\hline
\end{tabular}

